\title{
Prevalence and Distribution of Pterion in Adult Dry Human Skull and its Clinical Importance
}

\section{ABSTRACT}

Introduction: The pterion is a topographic point on the lateral aspect of the skull, where frontal, sphenoid, parietal and temporal bones meet. It lies in the anterior part of floor of the temporal fossa about $4 \mathrm{~cm}$ above the zygomatic arch and $3.5 \mathrm{~cm}$ behind the fronto-zygomatic suture.

Aim: To determine the prevalence of type and position of the pterion using the standard cranial anatomical points.

Materials and Methods: The present cross-sectional study was conducted from July 2020 to September 2020 in NSCB Medical college Jabalpur (M.P.). One hundred and eighty dry human skull obtained from Department of Anatomy. Sutural pattern of pterion were classified into sphenoparietal, frontotemporal, epipteric or stellate type. Position of pterion was also determined in relation to three specific bony landmarks. All parameters were evaluated bilaterally, observations tabulated and analysed using SPSS software version 23.
Results: In present study, it was found that $84 \%(n=180)$ skull posses sphenoparietal type of pterion bilaterally, then epipteric type $(7.73 \%)$ followed by frontotemporal $(6.61 \%)$ and the least variety was stellate type (1.83\%). The mean distance from upper end of zygomatic arch up to centre of pterion on right side was $35.12 \pm 4.1 \mathrm{~mm}$ and on the left side was $36.26 \pm 3.88 \mathrm{~mm}$. The distance from posterolateral margin of frontozygomatic suture up to centre of pterion on right side was $28.84 \pm 5.80 \mathrm{~mm}$ and on the left side was $30.10 \pm 4.79 \mathrm{~mm}$.

Conclusion: The study concluded that in present study, sphenoparietal type of pterion was most common bilaterally and stellate type was least common. The detailed data about the location of the pterion serves as a benchmark for neurosurgeons to localise the correct position for burr hole during all invasive surgeries.

\section{INTRODUCTION}

The word Pterion means 'wing' [1]. This $\mathrm{H}$-shaped suture is generally seen at the floor of temporal fossa covered by fan shape muscle Temporalis [2]. During the study of Norma lateralis of skull, the pterion is an important bony landmark seen as $\mathrm{H}$ or K-shaped suture. The pterion denotes the meeting point of four bones of skull. In this point, squamous part of frontal bone, sphenoid angle of parietal bone, squamous part of the temporal bone and greater wing of sphenoid bone meet [2]. In foetal skull, the pterion is a site of anterolateral fontanelle (sphenoidal fontanelle). These are unossified membranous gap present at the angles of parietal bones. The fontanelles provide for the moulding of the foetal head during its passage through the birth canal as well as the rapid growth of the brain during infancy. By the process of membranous ossification, the gap is filled by fibrous tissue generally at three months after birth $[3,4]$. For the first time, Broca (1875) classified three types of pterion (sphenoparietal, frontotemporal and stellate). In 1956, Murphy expanded the list with another type; the epipteric $[5,6]$. Murphy reported that variations of the pterion are likely a result of a combination of environmental and genetic factors. Population-based differences suggest that various genetic variations in humans underlie the different sutural patterns of the pterion (Wang et al.) [7]. In the sphenoparietal type, the sphenoid and parietal bones touch directly and form the suture, without the frontal and temporal bones making contact with one another. In the frontotemporal type, the frontal and temporal bones touch directly and form the suture, without the sphenoid and parietal bones making contact with one another. In the stellate type, frontal, parietal, sphenoid and temporal bones connect together at one point. The characteristic of the epipteric type are the presence of Wormian bones or sutural bones between the frontal, parietal, sphenoid and temporal bone [5,6]. The sutural bones are small irregular bones formed by additional ossification centres mostly in the region of fontanelles [2].
In neurosurgery, it is important to have the most suitable bony aperture in order to be minimally invasive. To achieve optimum craniotomy where neuronavigation devices are not available, the surgeon then relies on external landmarks such as pterion. The pterion is an important clinical landmark because deep to pterion there lies the middle meningeal vein, anterior division of middle meningeal artery and stem of lateral sulcus of brain. A strong blow to this region can fracture the bones around the pterion. If the underlying artery is damaged, it results as chief source of extradural haemorrhage. Initially, the injured person may be normal without any signs of underlying trauma (symptoms of unconsciousness) as there is lucid interval phase. So, if prompt diagnosis and treatment does not occur, fatality may happen. This implies that the neurosurgeon must locate the pterion centre precisely as drilling for cerebral decompression surgeries $[8,9,10]$.

For the past decades, a clear tendency to minimally invasive approaches has been observed in surgery of the anterior skull base. Technical development and interdisciplinary co-operation have made it possible to treat even complex pathologies. In this context, for example, improvements of the video-endoscopic displays, the development of special instruments, improvement of imaging, and performing surgeries together in the four-hands technique.

The present study was to be done to provide additional information about the exact location, type and mean distances from centre of pterion upto specific bony landmarks for all surgeons. The results shown epipteric type of pterion as a second most common variety. As this type of pterion can mistakenly be assessed to be at the most anterior junction of bones and a burr hole placed over there may cause inadvertent penetration into the orbit. So to avoid surgical pitfall, the neurosurgeons kept this finding and will take extra precaution before any surgery at the pterionic region of skull [11]. 


\section{MATERIALS AND METHODS}

It is a cross-sectional study performed in Department of Anatomy, N.S.C.B. Medical College Jabalpur (M.P.) in a duration of three months (two months for data collection and one month for data analysis). The source of data was human skulls in Department of Anatomy at N.S.C.B. Medical College Jabalpur (M.P.). The sample size was based on previous studies, 180 dry human skulls of Indian origin, of unknown age and sex.

Inclusion criteria: Only those skulls which were regular in shape, with no obvious deformity or malformation, and with the calvarium separated above the level of pterion were selected.

Exclusion criteria: Skulls with bilateral absence of pterion, due to breakage or synostosis.

Type (sutural pattern) of pterion was classified in accordance with Murphy's [6] criteria, into one of four types-sphenoparietal, frontotemporal, stellate or epipteric [Table/Fig-1,2,3,4]. Position of pterion was determined in relation to three specific bony landmarks in the skull. A circle of smallest diameter was drawn which passed through all the four bones converging at the pterion marked as Centre Point (CP). Linear distances were measured from the CP to the following specific bony landmarks $[12,13]$.
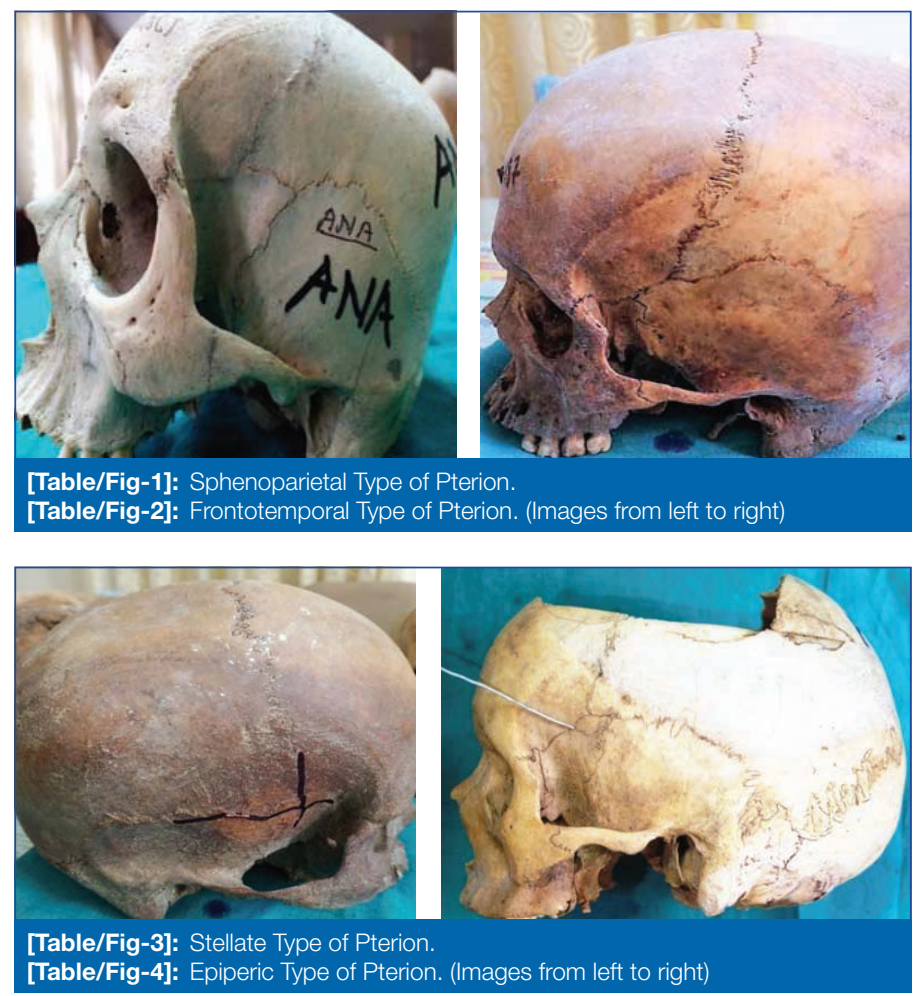

Linear distances were measured from the CP to the following specific bony landmarks-P-ZA-from CP of pterion to superior margin of zygomatic arch.

P-FZS-from CP to posterolateral margin of the frontozygomatic suture. All the above mentioned measurements were made using a digital vernier caliper with least count of $0.01 \mathrm{~mm}$ [Table/Fig-5,6].

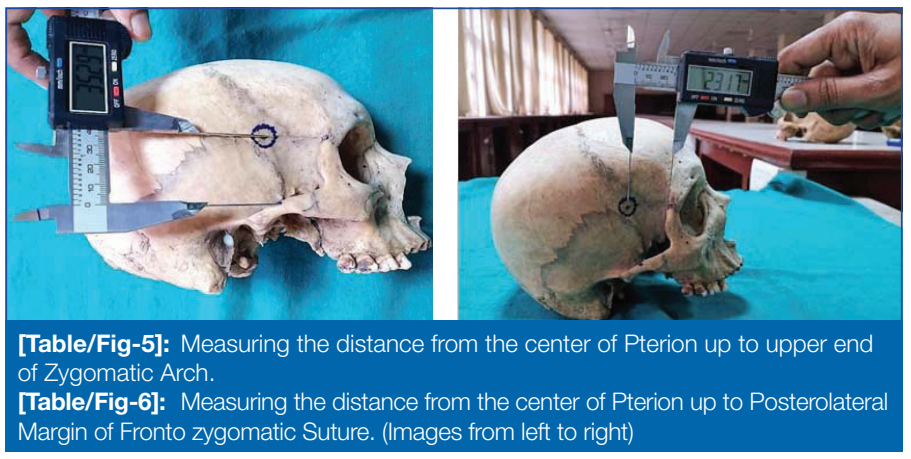

\section{STATISTICAL ANALYSIS}

All parameters were evaluated bilaterally, observations tabulated and analysed using Statistical Package for the Social Sciences (SPSS) software version 23.0. Student's t-test and p-value was also applied in the analysed data to make it significant.

\section{RESULTS}

The results were analysed and tabulated. In present study, 180 skulls means total 360 pterion on both right and left sides were studied. Out of 180 skulls, the most common type of pterion was sphenoparietal in $84.18 \%$ of skulls with slight more number on left side as compare to right. The second common type was epipteric type, then frontotemporal type and the least was stellate type [Table/ Fig-7]. Out of all 180 skull analysed in present study, total 173 skull (96.11\%) have same type of pterion on both sides. Only four stellate types and three epipteric type of pterion presented themselves unilaterally and on the other side there was a sphenoparietal type [Table/Fig-8]. The mean distances from the centre of pterion upto the upper end of zygomatic arch and posterolateral margin of frontozygomatic suture were displayed [Table/Fig-9] that shows the distances on left side was slightly greater than the right side on both parameters. If the values of both sides are compared, CPUZA become statistically insignificant ( $p$-value=0.07). The $p$-value obtained for CP-FZS ( $p=0.26)$ was also statistically insignificant on both sides ( $p \leq 0.05$ is significant).

\begin{tabular}{|l|c|c|c|}
\hline Pterion type & Right $(\mathrm{n}=\mathbf{1 8 0})$ & Left $(\mathrm{n}=\mathbf{1 8 0})$ & Both sides \\
\hline Sphenoparietal & $148(81.61 \%)$ & $155(86.76 \%)$ & $84.18 \%$ \\
\hline Fronto-temporal & $12(6.61 \%)$ & $12(6.61 \%)$ & $6.61 \%$ \\
\hline Stellate & $05(2.94 \%)$ & $01(0.73 \%)$ & $1.83 \%$ \\
\hline Epipteric & $15(8.82 \%)$ & $12(5.88 \%)$ & $7.35 \%$ \\
\hline
\end{tabular}

\begin{tabular}{|l|c|c|c|c|c|}
\hline Pterion type & $\begin{array}{c}\text { Sphenoparietal } \\
\text { left }(\mathrm{n})\end{array}$ & $\begin{array}{c}\text { Fronto- } \\
\text { temporal } \\
\text { left }(\mathrm{n})\end{array}$ & $\begin{array}{c}\text { Stellate } \\
\text { left }(\mathrm{n})\end{array}$ & $\begin{array}{c}\text { Epipteric } \\
\text { left }(\mathrm{n})\end{array}$ & $\begin{array}{c}\text { Total } \\
(\mathrm{n}=180)\end{array}$ \\
\hline $\begin{array}{l}\text { Sphenoparietal } \\
\text { right }\end{array}$ & 148 & 00 & 02 & 01 & 151 \\
\hline $\begin{array}{l}\text { Fronto- } \\
\text { temporal right }\end{array}$ & 00 & 12 & 00 & 00 & 12 \\
\hline Stellate right & 02 & 00 & 01 & 00 & 03 \\
\hline Epipteric right & 02 & 00 & 00 & 12 & 14 \\
\hline
\end{tabular}

\begin{tabular}{|l|c|c|c|}
\hline Distance & Right (mean+/-SD) & Left (mean+/-SD) & p-value \\
\hline CP-UZA (mm) & $35.12 \pm 4.1 \mathrm{~mm}$ & $36.26 \pm 3.88 \mathrm{~mm}$ & 0.07 \\
\hline CP- FZS $(\mathrm{mm})$ & $28.84 \pm 5.80 \mathrm{~mm}$ & $30.10 \pm 4.79 \mathrm{~mm}$ & 0.26 \\
\hline
\end{tabular}

[Table/Fig-9]: Relative position of pterion; $\mathrm{CP}=$ Central point of pterion. UZA=Upper
end of zygomatic arch

FZS: Frontozygomatic suture; $p$-value ( $\leq 0.05$ is significant) \{Students t-Test\}; SD: Standard deviation

\section{DISCUSSION}

The morphological and morphometric variations of the pterion have been detected in various populations. Pterion type is subject to evolutionary, ethnic and regional variations. In present study, the sphenoparietal type of pterion was most common variety bilaterally $(84.18 \%)$ that was an agreement with the past studies done by many Indian anatomists such as Sudha R et al., Hariprashad et al., Natekar PE et al., Dutt V et al., Seema and Mahajan A $[14,15,16,17,18]$. Current study results also matched with some studies done in foreign countries among their citizens as Australian aborigines by Murphy [6], Nigerian population by Adejuwon SA et al., [12]. Present study differs from studies done by Mwachaka PM et al., [19] among Kenyan skulls, Saheb SH et al., [20] in Indian skulls [Table/Fig10] [6,12-22]. This may due to different sample size and some genetic factor. The second commonest type of pterion observed was epipteric type (7.35\%). These are small irregular ossicles differ 
in number may be one, two or three formed due to additional ossification centres at the meeting point of cranial bones. This may serve as a marker for various underlying neurocranial abnormalities. Therefore, it is relevant to surgeons and radiologists to have this essential information before and during surgical intervention [21,22, 23]. The third commonest type is fronto-temporal type of pterion (6.65\%). Among previous studies its prevalence varying from $2.4 \%$ to $7.5 \%$. The fourth and last type of pterion in the present study was stellate type (1.83\%), prevalence ranged from $0.4 \%$ to $5.6 \%$.

\begin{tabular}{|c|c|c|c|c|c|}
\hline \multirow[b]{2}{*}{ Study } & \multicolumn{5}{|c|}{ Type of pterion } \\
\hline & $\begin{array}{l}\text { Sample } \\
\text { size }(n)\end{array}$ & $\begin{array}{c}\text { Sphenoparietal } \\
(\%)\end{array}$ & $\begin{array}{l}\text { Frontotermporal } \\
(\%)\end{array}$ & $\begin{array}{c}\text { Stellate } \\
(\%)\end{array}$ & $\begin{array}{l}\text { Epipteric } \\
(\%)\end{array}$ \\
\hline $\begin{array}{l}\text { Australian } \\
\text { aborigines- } \\
\text { Murphy- } \\
\text { (1956) [6] }\end{array}$ & 388 & $73 \%$ & $7.50 \%$ & $18.50 \%$ & $1 \%$ \\
\hline $\begin{array}{l}\text { Adejuwon, S. } \\
\text { A.,Olopade, F. } \\
\text { E. and Bolaji, } \\
\text { (2013) [12] }\end{array}$ & 37 & $86.10 \%$ & $8.30 \%$ & $5.60 \%$ & Nil \\
\hline $\begin{array}{l}\text { Nigerian- } \\
\text { Saxena et al. } \\
(1988) \text { [13] }\end{array}$ & 40 & $87.79 \%$ & $10.11 \%$ & $5.06 \%$ & $3.79 \%$ \\
\hline $\begin{array}{l}\text { Sudha R et } \\
\text { al., (2013) [14] }\end{array}$ & 150 & $80 \%$ & $03 \%$ & $5.30 \%$ & $11.30 \%$ \\
\hline $\begin{array}{l}\text { Hariprasad et } \\
\text { al. (2015) [15] }\end{array}$ & 60 & $89.20 \%$ & $3.30 \%$ & $05 \%$ & $2.50 \%$ \\
\hline $\begin{array}{l}\text { Natekar PE et } \\
\text { al., (2016) [16] }\end{array}$ & 150 & $85.33 \%$ & $08 \%$ & $10.60 \%$ & $51.54 \%$ \\
\hline $\begin{array}{l}\text { Dutt V et al., } \\
\text { (2017) [17] }\end{array}$ & 78 & $82.70 \%$ & $3.20 \%$ & $2.56 \%$ & $11.54 \%$ \\
\hline $\begin{array}{l}\text { Seema and } \\
\text { Anupama } \\
\text { Mahajan } \\
\text { (2014) [18] }\end{array}$ & 50 & $89 \%$ & $07 \%$ & $04 \%$ & $12 \%$ \\
\hline $\begin{array}{l}\text { Kenyans- } \\
\text { Mwachaka } \\
\text { PM et al } \\
\text { (2009) [19] }\end{array}$ & 79 & $66 \%$ & $15 \%$ & $12 \%$ & $07 \%$ \\
\hline $\begin{array}{l}\text { Hussain SS et } \\
\text { al. (2010) [20] }\end{array}$ & 125 & $69.25 \%$ & $17.35 \%$ & $9.70 \%$ & $3.70 \%$ \\
\hline $\begin{array}{l}\text { Japanese } \\
\text { Matsumura } \\
\text { (1991) [21] }\end{array}$ & 614 & $79.10 \%$ & $2.60 \%$ & $17.70 \%$ & $0.60 \%$ \\
\hline $\begin{array}{l}\text { Manjunath et } \\
\text { al. (1993) [22] }\end{array}$ & 172 & $93.55 \%$ & $3.52 \%$ & $2.93 \%$ & $17.30 \%$ \\
\hline $\begin{array}{l}\text { Present study } \\
\text { (2020) }\end{array}$ & 180 & $84.18 \%$ & $6.61 \%$ & $1.83 \%$ & $7.35 \%$ \\
\hline
\end{tabular}

Sutures are of great importance for craniofacial growth. The development of calvarial bones is tightly coordinated with the growth of the brain and requires interactions between different tissues within the calvarial sutures [24]. According to Nambi G [25] hypothesis, the pterion suture length is influenced by biomechanical stressors related to mastication [25]. The phylogenetic theory of formation of different types of pterion was given by Ahuja UK et al., [26]. According to this theory, the frontotemporal type of pterion was common in primates and sphenoparietal type was common in human beings. The anterosuperior segment of the squamous part of the temporal bone of the primates may have detached from the parent bone and got incorporated in the posterosuperior angle of the greater wing of sphenoid during phylogenesis, thus changing the pattern from frontotemporal to sphenoparietal type of the pterion. If however the desquestrated portion remained permanantly detached from both of the bones, it becomes the epipteric type.

Present observations among the laterality of pterion, it was clear from [Table/Fig-8] that bilateral same type of pterion of all three types was more common except in stellate variety. The reason behind this was not clear, but it seems to be correlate with the ethnicity, age, genetic factor and could be due to the different sample sizes used in the studies. This is an agreement with the findings among Indians Saxena RC et al., [27] but differs with that among Turks, where the occurrence of a different combination of pterion found on the left and right sides Oguz $\mathrm{O}$ et al., [28]. The mean distance from centre of pterion upto upper end of zygomatic arch and posterolateral margin of frontozygomatic suture were respectively $35.12 \pm 4.1 \mathrm{~mm}$ and $28.84 \pm 5.80 \mathrm{~mm}$ on right side. On the left side, the result was $36.26 \pm 3.88 \mathrm{~mm}$ and $30.10 \pm 4.79 \mathrm{~mm}$. The findings was also an agreement with previous studies done about mean distances that ranges between $35-45 \mathrm{~mm}$ in case of CP-UZA and 25-35 $\mathrm{mm}$ in respect to CP-FZS [Table/Fig-11] [15,17,18,20,29].

\begin{tabular}{|l|c|c|c|c|c|}
\hline \multirow{2}{*}{} & \multirow{2}{*}{\begin{tabular}{l} 
Sample \\
\cline { 3 - 6 }
\end{tabular}} & \multicolumn{2}{|c|}{ From FZS to CP } & \multicolumn{2}{|c|}{ From UZA to CP } \\
\cline { 3 - 6 } & Study populations (n) & Right & Left & Right & Left \\
\hline $\begin{array}{l}\text { Zalawadia et al., } \\
\text { (2010) [29] }\end{array}$ & 42 & $37.3 \pm 0.51$ & $35.5 \pm 0.42$ & $31.2 \pm 0.44$ & $29.7 \pm 0.33$ \\
\hline $\begin{array}{l}\text { Hussain S S et al., } \\
\text { (2010) [20] }\end{array}$ & 125 & $34.7 \pm 0.48$ & $34.0 \pm 0.45$ & $39.0 \pm 0.35$ & $37.8 \pm 0.35$ \\
\hline $\begin{array}{l}\text { Seema and Mahajan } \\
\text { et al., (2014) [18] }\end{array}$ & 50 & $31.0 \pm 0.44$ & $34.0 \pm 0.40$ & $41.0 \pm 0.45$ & $44.0 \pm 0.32$ \\
\hline $\begin{array}{l}\text { Hariprasad et al., } \\
\text { (2015) [15] }\end{array}$ & 50 & $32.0 \pm 0.39$ & $31.1 \pm 0.40$ & $37.1 \pm 0.39$ & $36.8 \pm 0.35$ \\
\hline $\begin{array}{l}\text { Dutt V et al., (2017) } \\
\text { [17] }\end{array}$ & 78 & $29.35 \pm 3.60$ & $27.37 \pm 5.80$ & $38.15 \pm 3.67$ & $36.69 \pm 3.64$ \\
\hline $\begin{array}{l}\text { Present study } \\
\text { (2020) }\end{array}$ & 180 & $28.84 \pm 5.80$ & $30.10 \pm 4.79$ & $35.12 \pm 4.1$ & $36.26 \pm 3.88$ \\
\hline
\end{tabular}

\section{Limitation(s)}

The study do not have a record about the male and female skulls.

\section{CONCLUSION(S)}

The results on the variations of pterion, its prevalence, mean distances from standard anatomical points was more consistent with previous studies. Sphenoparietal type was most common on both sides. Previous studies and present study have different observation for second and third most common type of pterion. The study also concluded that the pterion types on both sides of skulls were same in most of the samples. But it was not a rule in all cases. The knowledge of the sutural morphology of the pterion with the obliteration of it, as well as the verification of the distance with a cranial anatomical point offer a great support in the clinical and forensic field. The present information may be applicable with other commonly used method like radiological analysis for better prediction of different type of sutural morphology.

\section{REFERENCES}

[1] Collins Dictionary. Glasgow. In. Alter. of GK Pterón Wing, on Model of Inion. $1^{\text {th }}$ Ed. Harper Collins Publishers Ltd. 2018. 1875-80 Www. Collins Dictionary. Com.

[2] Williams Pl, Bannister LH, Berry MM, Collins P, Dyson M, Dussek JE. The Skull. In. Gray's Anatomy, 38 ${ }^{\text {th }}$ Ed. London: Churchill Livingstone; 1995. P. 560.

[3] O'rahilly R, Müller F. Human Embryology And Teratology. 3rd Ed. New York: Wiley-Liss, 1996.

[4] Standring S. Gray's Anatomy. The Anatomical Basis of Clinical Practice. 41st Ed. New York, Elsevier, 2016.

[5] Broca P. Instructions Craniologiques Et Craniometriques. Mem. Soc. Anthrop. 1875;2:01-203.

[6] Murphy T. The Pterion in Australian Aborigine. American Journal of Physical Antropology, 1956;14:2;225-244.

[7] Wang Q, Opperman LA, Havil L.M, Carlson DS, Dechow PC. Inheritance of sutural pattern at the pterion in rhesus monkey skulls. Anat Rec Discov Mol Cell Evol Biol. 2006;288:1042-9.

[8] Lama M, Mottolese C. Middle meningeal artery aneurysm associated with meningioma. J Neurosurg Sel. 2000; 44:39-41.

[9] Lindsay K, Bone I, Callander R. Neurology And Neurosurgery Illustrated. 2nd Edn. Churchill Livingstone, Hongkong 1991; 312-14

[10] Chandana B, Saralaya V, Kishan K. Pterion: A site for neurosurgical approach article in international journal of biomedical research. 2012;2;588-94. 
[11] Ersoy M, Evliyaoglu C, Bozkurt MC, Konuskan B, Tekdemir I, Keskil IS. Epipteric bones in the pterion may be a surgical pitfall. Minim Invasive Neurosurg. 2003;46(6):363-65

[12] Adejuwon SA, Olopade FE, Bolaji M. Study of the location and morphology of the pterion in adult nigerian skulls. Isrn Anat., 2013:403937.

[13] Saxena SK, Jain SP, Chowdhary DS. A comparative study of pterion formation and its variations in the skulls of nigerians and indians. Anthropol Anz 1988;46:75-82.

[14] Sudha R, Sridevi C, Ezhilarasi M. Anatomical variations in the formation of pterion and asterion in south indian population. Int J Cur Res Rev. 2013;05(09):92-101.

[15] Hariprasad, Bezbaruah NK, Mishra A, Mishra PP. Morphometric analysis of pterion: A clinic-anatomical study in north indian dry skulls. Innovative Journal Of Medical And Health Science. 2015;5(5):201-05.

[16] Natekar PE, Desouza FM, Natekar SP. Pterion: An anatomical variation and surgical landmark. Indian Journal of Otology. 2011;17(2):83-85.

[17] Dutt V, Shankar W, Shetty S. Morphometric study of pterion and asterion in adult human skulls of Indian origin. Int J Anat Res. 2017, 5(2.2):3837-42.

[18] Seema, Mahajan A, Pterion formation in north indian population: An anatomicoclinical study. Int J. Morphol. 2014;32(4):1444-48.

[19] Mwachaka PM, Hassanali J, Odula P. Sutural morphology of the pterion and asterion among adult kenyans. Braz J Morphol. Sci. 2009;26(1);04-07.

[20] Saheb SH, Mavishetter GF, Thomas ST, Prasanna LC, Muralidhar P. Anatomical position of pterion among the indian for lateral skull approach. Biomedicine. 2010;30 (3):391-393.
[21] Matsumura G, Kida K, Ichikawa R, Kodoma G. Pterion and epipteric bones in japanese adults and fetuses with special reference to their formation and variations. Kaibagaku Zasshi. 1991;66:462-71.

[22] Manjunath $\mathrm{KY}$, Thomas IM, Pterion variants and epipteric ossicles in south indian skulls, J Anat Soc India. 1993;42:85-94.

[23] Opperman, LA. Cranial sutures as intramembranous bone growth sites. developmental dynamics. 2000;219:4.

[24] Kim HJ. Rice DPC, Kettunen PJ, Thesleff I. FGF-, BMP- and SHH-Mediated signaling pathways in the regulation of cranial suture morphogenesis and calvarial bone development. 1998;125(7);1241-51.

[25] Nambi G. Investigating pterion from two perspectives: Phylogenetics and biomechanics (2017) WWU graduate school collection https://cedar.wwu.edu/ wwuet/580.

[26] Ahuja UK, Mukerjee RN, Singh B. Pterion-Its formation and variation. J Anat Soc. Ind. 1971; 20(2):103-11.

[27] Saxena RC, Bilodi AK, Mane SS, Kumar A. Study of pterion in skulls of Awadh area-in and around Lucknow. Kathmandu Univ Med. J. (KUMJ). 2003;1(1):32-33.

[28] Oguz O, Sanli SG, Bozkir MG, Soames RW. The pterion in Turkish male skulls. Surg Radiol Anat. 2004; 26(3):220-24.

[29] Zalawadia A, Vadgama J, Ruparelia S, Patel S, Rathod SP, Patel S. Morphometric study of pterion In dry skull of Gujarat region. National Journal of Integrated Research in Medicine. 2010;1(4):25-29.

PARTICULARS OF CONTRIBUTORS:

1. Assistant Professor, Department of Anatomy, NSCB Medical College, Jabalpur, Madhya Pradesh, India.

2. Assistant Professor, Department of Anatomy, NSCB Medical College, Jabalpur, Madhya Pradesh, India.

3. Associate Professor, Department of Anatomy, NSCB Medical College, Jabalpur, Madhya Pradesh, India.

\section{NAME, ADDRESS, E-MAIL ID OF THE CORRESPONDING AUTHOR:}

Dr. Nidhi Agrawal,

QR No. F23, Doctor Colony, Medical College Campus,

Jabalpur, Madhya Pradesh, India.

E-mail: rdrnidhi1995@rediffmail.com
PLAGIARISM CHECKING METHODS: [Jain Het al.]

- Plagiarism X-checker: Oct 17, 2020

- Manual Googling: Dec 08, 2020

- iThenticate Software: Feb 17, 2021 (25\%)
ETYMOLOGY: Author Origin

\section{AUTHOR DECLARATION:}

- Financial or Other Competing Interests: None

- Was Ethics Committee Approval obtained for this study? NA

- Was informed consent obtained from the subjects involved in the study? NA

- For any images presented appropriate consent has been obtained from the subjects. NA
Date of Submission: Oct 17, 2020

Date of Acceptance: Dec 08, 2020

Date of Publishing: Apr 01, 2021
Date of Peer Review: Nov 09, 2020 